\title{
An ergonomic study on the biomechanical consequences in children, generated by the use of computers at school
}

\author{
Claudia Paraizo, ${ }^{1}$ and Anamaria de Moraes $^{2}$ \\ ${ }^{I}$ Pontifical Catholic University (PUC-Rio) LEUI-PUC-Rio Laboratório de Ergonomia e Usabilidade de \\ Interfaces (Ergonomics and Interface Usability Laboratory) - Brazil cbparaizo@gmail.com \\ ${ }^{2}$ Communication Faculty, Federal University of Rio de Janeiro (ECO/UFRJ) LEUI-PUC-Rio, Ergonomics and \\ Interface UsabilityLaboratory) - Brazil moraergo@rdc.puc-rio.br
}

\begin{abstract}
This res earch d eals with the infl uence of the computer use in sch ools related to the children po sture, in an ergonomic point of view. The research tries to identify probable causes for the children early postural constraints, relating it to the sedentary behavior and the lack of an ergonomic project in schools. The surv ey involved 186 children, between 8 and 12 years old, students of a private school in Rio de Janeiro - Brasil.

An historical an $d$ theoretical school furniture $r$ esearch was co nducted as well as a survey wi th the students and teachers, computer postural evaluation, ergonomic evaluation (RULA method), and observations in the computer classroom.

The research dealt with the student's perception with respect to the furniture utilized by him in the classroom during the use of the computer, his body complaint, the time he spent working on the school com puter and the pos sibility of the existence of sedentariness. Also deals with the teachers' perception and knowledge regarding ergonomics w ith reference to schoolroom furniture and its Regulatory Norms (RN). The purpose of the res earch work is to highlight the importance of this knowledge, having in view the possibility of the teachers' collaboration in the ergonomic adaptation of the classroom environment and in their conscientious opinion during the pur chasing of this furni ture. A questionn aire was util ized and its results sh owed some discontent on the part of the teachers with $r$ elation to the $s$ choolroom furniture as well as th e teachers' scant kno wledge of Ergonomics.

We conclude with a survey that despite the children had constraints in postural assessments and school furniture needs a major ergonomic action, the time that children use the computer at school is small compared $w$ ith the time of use at home and therefore ins ufficient to be the main caus e of quantified commitments, thus the s tudy of co mputer us e at home as a development and continuity of this research.
\end{abstract}

Keywords: ergonomics; computer; child; school furniture; postural constraints

\section{Introduction}

The technology and the information are considered the hallmark of the contemporary world, where objects, goods and furnishings are designed and constructed with the objective to promote the convenience, comfort and beauty, but many times, these too become bothering and damaging the structure man's physical, not to adapt the measures and activities of the users of the task, thus causing pathological and adaptive postures.

The child's body in the growth phase is in continuous change, growth occurs first in the limbs (legs) and later in pre -puberty and early puberty in the trunk (VIEL; Esnault, 2004). So there should be special attention to the lower limbs because of their 
influence on the curvature of the spine. Considering that very early the child remains seated for long hours in school, there is a need to vary the distance chair - work surface, especially in classrooms that welcome children and adolescents during puberty. Because of this istinction is significant at these periods in terms of comfort of the child to sit (VIEL; Esnault, 2004).

The child's body in the growth phase is in continuous change, growth occurs first in the limbs (legs) and later in pre-puberty and early puberty in the trunk (VIEL; Esnault, 2004). So there should be special attention to the lower limbs because of their influence on the curvature of the spine.

Considering that very early the child remains seated for long hours in school, there is a need to vary the distance chair - work surface, especially in classrooms that welcome children and adolescents during puberty. Because of this distinction is significant at these periods in terms of comfort of the child to sit (VIEL; Esnault, 2004).

Another observation in this regard held by Floyd \& Ward (apud PASCHOARELLI, 1997), demonstrates that the postures are the most frequent of students sitting without leaning on the back and / or the upper body leaning forward and both arms resting on the table.

Moraes (1992) also states that the pressure on the intervertebral discs is $40 \%$ higher when sitting compared to standing posture, even with the trunk erect. When flexing (bending forward) the trunk gets worse, because in this case has a pressure of $90 \%$ compared to the standing position and may lead to injury over time in both the intervertebral disc (hernia) as the vertebrae (bone spurs) and even in peripheral areas of the spine.

Nachemson and Jonsson (2000) in its research, had evidenced that the record to the being inclined for front in only $8^{\circ}$, increase the intradiscal pressure in $1,5 \mathrm{~kg} / \mathrm{cm} 2$, what it corresponds $20 \mathrm{~kg}$ of external load approximately. This in the ones of the one notion of as we overload our records and ligaments when we bow our trunk to "address that," for example, over a keyboard to write. .

According to Moraes (1983), the positions taken are as levers to offset the weight of the head and trunk, and poor spinal posture while sitting, according to studies by several authors as Corlett, Manerica \& Wilson (1986) and Mandal (1981), are the cause of back pain, especially in the neck, buttocks and lower back.

\subsection{School furniture}

The issue of school furniture should not be treated outside of a broad context of learning and education. Although the design of school furniture has technical features and specific criteria, it is essential that the subject is always embedded in a larger context. You have to understand and analyze a variety of issues through education to establish relations of furniture with the educational criteria, ergonomic and technological (Bergmiller, 1999).

\subsubsection{Regulatory standards for school furniture}

In European countries like England, France, Portugal, among others, and Asia such as Japan, the evaluation of the quality of school furniture used in public schools is subject to verification of compliance with specific standards for these products.

These rules provide standards for verification in addition to dimensional criteria and methods for evaluating product performance, in terms of their structural strength and integrity when subjected to impact and shock, a condition resulting from actual use.

The school furniture is an important variable in the Brazilian educational context, the process includes several steps (specification, design, development, measurement, budgeting, procurement, manufacturing, shipping, receiving, assembly, distribution, installation, operation, maintenance and evaluation use) associating the large investments and a large number of institutions involved.

The publication of specific standards for furniture, by CB-15, starts from 1992, replacing specifications uncomplicated integrated normative documents of other committees of the ASME, as the CB-2 / Brazilian Committee of Construction, for example. Methods have been developed to make the process more transparent furniture, through the moralization of the acquisition phase, the organization of the production phase and monitoring phase of receipt and maintenance. In 1997, ABNT published two standards relating to school furniture:

- NBR 14006 - school furniture - Seating and tables for educational institutions - Classes and dimensions;

- NBR 14007 - school furniture - Seating and tables for educational institutions - Requirements, recommendations dealing with ergonomic (posture) and anthropometric (size). with 
Norm 14006 in acordance established a total of 07 standard of dimensional classrooms for table and pertaining to school chair the stature of child since preschool age until adult individuals. The first two classes provided are aimed at younger children, the following four elementary school students and adults at last, ensuring correct posture while sitting, health protection and structuring the user's body.

These standards have undergone a review in 2003, and standard 14007 has been incorporated in the standard 14006, forming a single reference.

These documents were a key point of information and standardization of school furniture for projects developed in Brazil.

With regard to the manufacturer, the domestic industry was developed from the need for import substitution, which bet on copies rather than invest in the creation and technological innovation.

The school furniture comes with low quality and durability; there is little care in the preparation of technical specifications. There is misalignment between meeting the needs of schools and the purchase made by the central organs. The furniture is unsuited to age group to which it is intended, due to the lack of pedagogical and ergonomic criteria, lack of care and technical criteria for the receipt and verification of the furniture to the specifications.

The lack of evaluation of design and resistance is also constant, being used mostly machines, latest technology combined with rudimentary practices, resulting in poor quality products. The furniture should be adapted to regional differences and teaching situations. Although the design of school furniture has technical features and specific criteria, it is essential that the subject is always embedded in a larger context.

Considering the information on posture and school furniture, we conducted a survey that sought to achieve the goals of observing the lack of ergonomic school furniture and computer-intensive, considering the physical and organizational and document the importance of Ergonomics in Schools Project - Meetings Computing. We believe that the independent variable was the lack of ergonomically designed school environments the growth was dependent on the number of children and adolescents with postural deviations and injuries and repeated movements of the taxpayer, the physical and mental constitution of the developing child.

\subsection{Posture}

The American Academy of Orthopedics defines the position as the state of balance between muscle and bone with the capacity to protect the other structures of the body from trauma, either while standing, sitting or lying (Adams, Daniel, Rullman \& McCubbin, 1985). Norris (1990), in turn, says that the posture is in a stable relationship between subject and medium, resulting in stabilization of space.

Thus, when the individual finds himself, has the impression of stability in the space it occupies.

According to Kendall (1995), poor posture is a faulty relationship between the various parts of the body that produces a greater strain on the supporting structures, and where there is a less efficient balance of the body on its base of support.

The spine consists of five regions: cervical (seven vertebrae), thoracic (twelve vertebrae), lumbar (five vertebrae), sacrum (five fused vertebrae) and the cocigea region (four vertebrae). This gives a total of 33 vertebrae, with 24 of them forming distinct regions: cervical, thoracic and lumbar (illustration 17), being present between the vertebrae are intervertebral discs that in all except the spine between the first and second cervical vertebra (Netter,2003).

The function of the spine is to protect the spinal cord, movement and gait, maintaining the upright position, support the body weight and connection of all its regions from the occiput to the sacrum, being a surface of insertion for muscles and ribs. According to Kapandji (2000) the spine is the axis of the body and must reconcile two contradictory imperatives mechanical: the rigidity and flexibility.

The spine when analyzed in order before or after it has shape and rectilinear when viewed in profile has four curvatures physiological plane anteroposterior or sagittal planes, which are called for: cervical lordosis and lumbar considered physiological up to $35^{\circ}-40^{\circ}$, has is slightly above; dorsal kyphosis and sacral, slightly later, considered the first a normal curvature of the spine when presented with an angle between 35 and 40 degrees.

The two curves that have a posterior convexity (concavity above) are termed kyphotic curves (thoracic and sacral). The two regions with concave posterior are the cervical and lumbar (convexities older) are called lordotic curve. The rachis is concave forward, getting straight to 13 
months. From the age of three there is a slight lumbar lordosis, which grows to 8 years old. The final curvature of the spine is reached at 10 years (Settineri, 1988).

\subsubsection{Postural impairments}

Children and adolescents who frequently use the computer may be exposed to develop pains, injuries and syndromes in the musculoskeletal system (Castellanos, AL, 2004) due to poor posture they assume for such activity.

Poor posture, as defined by Kendal (1995), is a faulty relationship between the various parts of the body that produces a greater strain on the supporting structures, and where there is a less efficient balance of the body on its base of support.

Among the diverse pathologies can be highlighted the scoliosis, which is translated as a lateral deviation of the spine in relation to the main axis of the same, the correction of kyphosis and physiological curves of the spine.

\section{Methods}

The survey consisted of evaluation of 86 elementary school children, aged between 09 and 12 years, questionnaires were administered to 186 children and 07 teachers.

Instruments were used to collect data for ergonomic evaluation:

- Observational Assessment of Computer Room and the user interaction with the computer.

- RULA

- Survey and questionnaire Closed

- Postural Assessment Computed

\subsection{Note computer room}

During the observational assessment of the computer room and the user interaction with computers, we considered the concepts and parameters ergonomic and task analysis activities through photos and footage (Video).

Computers, according to their own children who participated in the survey, were used individually or in pairs.

\subsection{Questionnaire}

The questionnaire was administered to 186 students in their classrooms. The same issues that had concerned: the comfort of using the table and chair in the classroom, computer to computer use and issues related to child health.

Were performed 16 (sixteen) questions.

Was applied to 07 teachers of the classes in which students participated in the survey, a questionnaire enclosed with an open question. The questions were related to the teachers' knowledge about ergonomics and the same opinion as to comfort the table and chair used by students in the school computer room. We carried out eight (08) questions.

\subsection{Postural assessment computed}

For Postural Assessment Computed was used "software" Posturograma. This research proposes to postural deviations and changes in the musculoskeletal system through the measurement of posture through scanned images(photos).

We used to just four (04) images: the anterior or posterior position of the front, or anterior posterior back, right profile and flexion (ventral view).

\section{Results}

\subsection{Observational results of the computer room.}

It was observed that:

-The chairs have fixed si ze, no hei ght adjustment, and were placed in pairs to use;

-Computers are distributed at tables still do not have ancillary ele ments to improve height, visibility and brightness, or footrest. Al 1 are prese nted i n great condition for use and did not ob serve the presence of loose wires around the classroom

-The atm osphere of the room w as bright an d had good cooling.

\subsection{Ergonomic assessment (RULA)}

The outcome of the evaluation with the RULA tool, it was reco rded th at $61.54 \%$ were in actio $n$ level 2, which indicates that more studies are needed and that $\mathrm{c}$ hanges a re re quired; $23.08 \%$ were i $\mathrm{n}$ Action Le vel 3, which i ndicates t hat research i s needed and changes in the near future, $15.38 \%$ were in Act ion Le vel 4, w hich i ndicates t hat requi re immediate changes as a graph. 
Chart 1

Results RULA Rating Tool

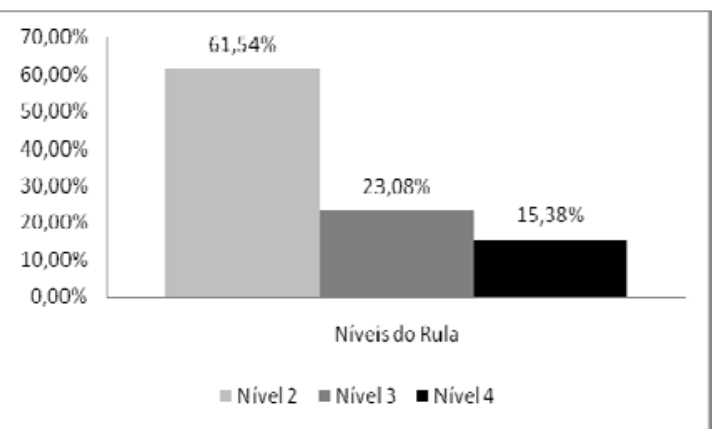

\subsection{Postural assessment Computed}

This assessm ent co ncluded t hat $100 \%$ of $t$ he children $p$ resented any type of $p$ ostural $d$ eviation, there is a connection bet ween them. The deviations were recorded, as Graph 2:

- anterior head $(51.16 \%)$

- Lateral deviation of the head $(8.13 \%)$

- Cervical Correction (26.74\%)

- Left shoulder higher $(55.81 \%)$

- Right shoulder highest (15.11\%)

- Wrapping the shoulders $(16.27 \%)$

- Kyphosis (11.62\%)

- hyperlordosis $(13.95 \%)$

- Rectification lumbar (6.97\%)

- Right Hip highest (41.86\%)

- Left Hip highest (19.76\%)

- Scoliosis (24.41\%)

- Rotation of return (13.95\%)

Chart 2:

Postural Assessment Results

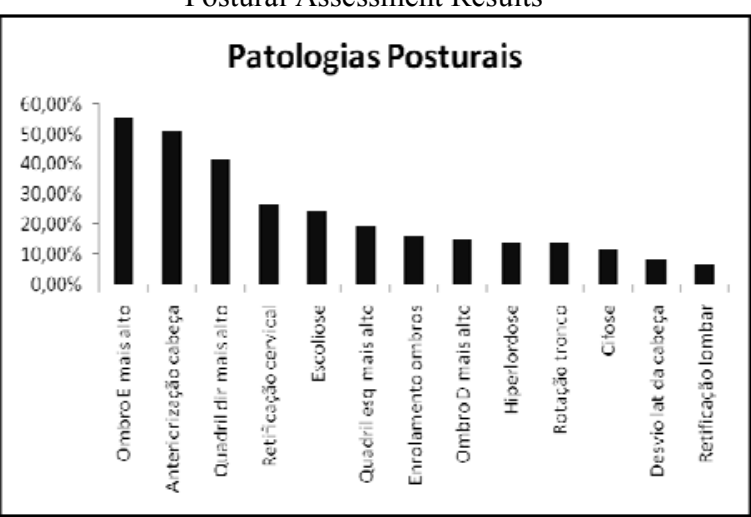

\section{Conclusion}

The observations made in this research led us to believe i $\mathrm{n} t$ he exi stence of problems i $\mathrm{n}$ sc hool furniture of the computer room, especially whe $n$ it comes to the same standardization and the lack of an ergonomic st udy for this en vironment. Building on these stud ies, w e question ho $\mathrm{w}$ th e d esign and ergonomics can in terfere with sp atial org anization within the school and its culture, in view

there is a un ique edu cational so cial $\mathrm{p}$ attern, with adequate $\mathrm{s}$ pace and furnis hings, es pecially with different physical, cognitive and organizational.

There is a problem of public policy and education in relatio $\mathrm{n}$ to $\mathrm{p}$ ostural $\mathrm{d}$ isorders of children and, if there is a ti mely intervention in the future we $m$ ay $h$ ave th e ex istence of an economically active population sick and may impact the health system.

Considering how we have seen that educational technology $h$ as b ecome ess ential to th e $u$ se of computers, we can not minimize the problem.

\section{References}

[1] Bergmiller, K ., \& Afflalo, B. Ensino Funda mental: Mobiliário Escola $r$ - Séri e Cadernos Técnicos. Brasíl ia / DF. Fundescola - Mec., 1999.

[2] Castellis, M. Fluxos, Rede s e Identidades: u ma te oria crítica da Socieda de Informacional in Novas perspecti vas críticas em educação. Porto Alegre: Artes Médicas, 1996

[3] Corlett, N. ; Wilson, J. ; Manenica, I. T he er gonomics of working postures. London: Taylor \& Francis, 1986.

[4] Gomes, V. B., Moraes, A. Er gonomia e Custos Hu manos Posturais do T rabalho Sentado em Atividades Técnicos Administrativas. Produto \& Produção, Por to Alegre, v. 4, n. 3 , p. $40-61,2000$

[5] Jacobs K. and B aker N. A., T he association betw een children's co mputer use and musculoskeletal disco mfort. Work: Jour nal of Pr evention Assess ment \& Rehabilitation, 18(3), 221-226, 2002

[6] Kapandji, I.A. Fisiologia Articular- Esquemas comentados de Mecânica Humana Volume 3 Ed. Manole, 2000 Kendall, H. O. Músculos- Provas e Funções. São Paulo, Manole, 1995

[7] Knoplich J. A. Coluna Ver tebral da $\mathrm{Cr}$ iança e do Adolescente Ed. Panamed, São Paulo. 1985

[8] Mandal, A. C. The Seated M an (Homo Sedens). The seat work position. Theory and pr actice. Applied E rgonomics, 19-26. 1981

[9] Moraes, A. Diagnóstico er gonômico do p osto de trabalho do di gitador. T ese de Doutor ado. v 3. E scola de comunicação; Universidade do Rio de Janeiro, 1992

[10] Moraes, Ana maria de, M ont'Alvão, C. E rgonomia: conceitos e aplicações - Rio de janeiro:2AB, 2010

[11] Moro, A. R. P. Er gonomia da sala de aula: constrangimentos post urais impostos pelo mobiliário 
escolar. Lec turas educacion fisica y deportes (Buenos

Aires), http://www.efdeportes.com/, v. 85, n. ano 10, 2005.

[12] Nachemson A; J onsson E . Neck and back pain: The

Scientific E vidence of Cause s, Diagnosis, and

Treatment. Philadelphia: Lippincott, Williams \& Wilkins, 2000

[13] Netter, F. H. Atlas de Anato mia Hu mana. $3^{\mathrm{a}}$ ed Art med: Porto Alegre, 2003

[14] Paschoarelli, L .C. O posto de trabalho carteira esco lar como objeto de d esenvolvimento d a educação in fantil uma contribuição do design e da ergonom ia. Bauru, 1997 121p. Dissertação de Mestrado em Desenho Industrial da Faculdade de Arquitetura, Art es e Co municação da Universidade Estadual Paulista Campos Bauru.

[15] Viel, E; Esnault M. Lo mbalgias e cervicalgias da posição sentada. São Paulo: Manole, 2000

[16] Zapater, A.R.ET AL. Postura sentada: A ef icácia de u m programa de ed ucação para escolares. Ciênc. sa úde coletiva, Rio de Janeiro, v. 9, n. 1, 2004. 